\title{
General Psychiatry Coping strategies used by families in Indonesia when caring for patients with mental disorders post-pasung, based on a case study approach
}

To cite: Yunita FC, Yusuf A, Nihayati HE, et al. Coping strategies used by families in Indonesia when caring for patients with mental disorders post-pasung, based on a case study approach. General Psychiatry 2020;33:e100035. doi:10.1136/ gpsych-2018-100035

Received 20 November 2018 Revised 07 May 2019 Accepted 28 November 2019

A) Check for updates

(c) Author(s) (or their employer(s)) 2020. Re-use permitted under CC BY-NC. No commercial re-use. See rights and permissions. Published by BMJ.

Department of Psychiatry and Community Health Nursing, Faculty of Nursing, Universitas Airlangga, Surabaya, Jawa Timur, Indonesia

Correspondence to Fildzah Cindra Yunita; fildzah.cindra-13@fkp.unair. ac.id

\section{ABSTRACT}

Background Treatment of post-pasung (physical restraint) patients with mental disorders has become a new problem in Indonesia in its effort to free the country from the physical restraint programme. Problems emerge when the patient returns to the family and society at large, and families that refuse to allow the patient to come back home risk the possibility that the patient may eventually become a psychotic vagrant.

Aims To determine the appearance of families taking care of patients with mental disorders post-pasung.

Method This study was qualitative research using a case study approach. The number of participants from six families was selected by purposive sampling. Collecting data was done by in-depth interview, and analysed thematically using Colaizzi steps.

Results The results showed that families coping when taking care of patients with mental disorders post-pasung comprise seven themes. The seven themes are formed by four categories, 19 sub-themes and 32 sections.

Discussion The appearance of coping was the overall description of coping in the form of strategic process stages, the support of coping and meaning for what the families feel when they are taking care of a patient with a mental disorder post-pasung. The appearance of coping showed how the family chooses the mechanisms of coping to deal with stress and crisis.

Conclusion The coping mechanisms that families use when taking care of a patient with a mental disorder post-pasung were formed through stages of a strategic process. Families need coping strengthening interventions to provide optimal care for patients with mental disorders post-pasung.

\section{INTRODUCTION}

Pasung is an illegal practice employed for patients with mental disorders, which has become a serious problem in Indonesia. Pasung of the patient with a mental disorder has been conducted by non-professionals or individuals associated with the patient; usually they chain the patient's legs using wooden blocks to control and remove the patient's freedom to move. ${ }^{1-3}$
The post-pasung patient with a mental disorder will be at risk of re-pasung activities by their family. This is because those patients who have been discharged from medical treatment at the psychiatric hospital often experience a relapse due to the infrequent consumption of medicine or due to consumption of many drugs at one time. Families consider that sending a patient with a mental disorder to healthcare facilities or alternative health services is expensive, expends too much energy, and does not lead to any significant improvement in the patient's mental health. ${ }^{4}$ The patient's condition will usually last forever and become a burden or stressor for the family. In order to resolve these problems, families develop coping mechanisms to avoid the risk of re-pasung in patients with mental disorders.

National Health Research in 2013 showed that the number of severe mental disorder cases reached 1.7 per million. The proportion of patients who had ever experienced pasung by their family was $14.3 \%$ and the largest percentage came from the rural population $(18.2 \%)$ with the lowest ownership index interval (19.5\%). In December 2016, there were 741 cases of families with a post-pasung patient with a mental disorder in East Java province, spread over 38 districts or cities. ${ }^{5}$ According to data from Jember District Social Service, up to January 2017, 95 cases were recorded, with patients in 61 cases released from seclusion/restraint.

Families of a patient with a mental disorder may endure high levels of conflict, with the patient becoming an objective and subjective burden, causing family members to blame one another and resulting in family feuds. The burden borne by families who are living with people with a severe mental disorder include several economic and social factors. In addition, the burden will become a lifelong stress, leading to ineffective coping. ${ }^{6}$ Stressors can be 
physical, financial and psychological, and can exacerbate the stress level of the family. Family stress theory explains that crises can arise from several sources, and if adaptive strategies do not effectively deal with the threats of stressors, then family members have no skill in resolving problems and become less useful. The crisis or family stress is characterised by family instability and unrest. ${ }^{7}$ The family stress experienced will affect the way family members treat the post-pasung patient with a mental disorder. Therefore, families need coping strategies to deal with the stress. Coping is a cognitive and behavioural effort to manage certain external/internal demands that overload or exceed the limits of the resources within an individual. A coping strategy is a change from one condition to another as a way to deal with unexpected situations. ${ }^{8}$

\section{METHOD}

This study aimed to explore the appearance of family coping when taking care of a post-seclusion or postrestraint (post-pasung) patient with a mental health disorder. A qualitative method with a case study approach was used. The period of research was from January to June 2017.

\section{Participants}

The research population comprised families each with a family member suffering from a mental disorder. The sample was obtained by purposive sampling. The inclusion criteria were families who were living with a post-pasung patient with a mental disorder, could communicate well, and were aged $>20$ years. Six families were enrolled. The participants were recruited on the basis of ethical principles (confidentiality, beneficence, and informed consent) (figure 1).

\section{Data collection and analysis}

The interview guidelines were developed based on the standard questionnaire of ways of coping by Folkman and Lazarus, ${ }^{9}$ Coping Health Inventory for Parents (CHIP) by McCubbin and Patterson, ${ }^{10}$ and theory of stress adaptation by Stuart. ${ }^{11}$ Before the data collection, the researchers carried out interview guidance trial tests on two participants to validate the questions.

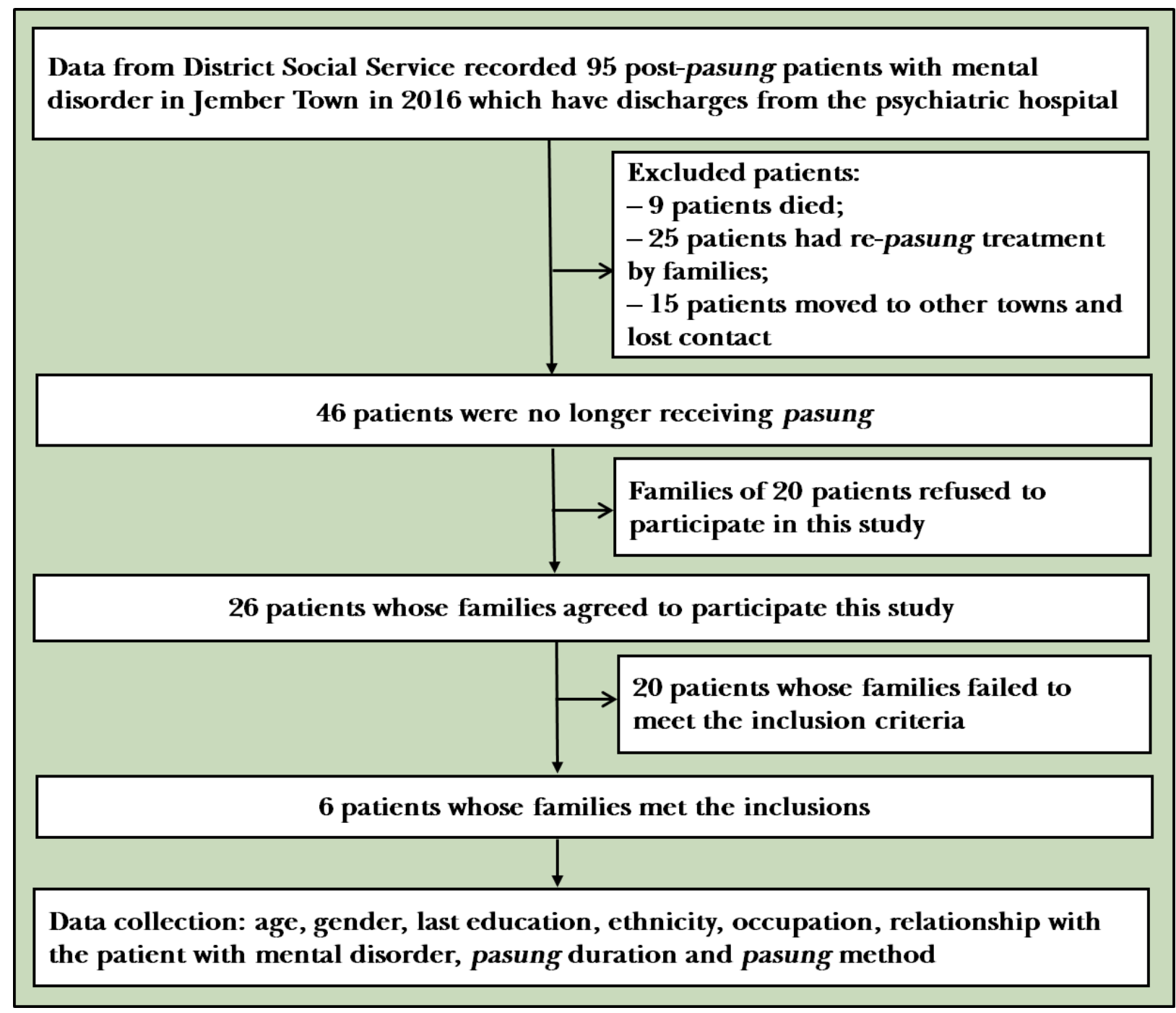

Figure 1 Flowchart of the participants' enrolment. 
Researchers approached the participants by conducting interviews at confirmed places. Researchers conducted crosschecks and compared the information obtained with other family members to avoid errors. The interview process was done until new unidentified themes appeared. Researchers used stationery and a recorder as data collection tools. The interview results were written as verbatim transcripts and created after each participant had finished being interviewed.

Data analysis was done using Colaizzi's ${ }^{12}$ method, which was started by recording the interview in written form (verbatim). Afterward, all verbatim transcripts were read repeatedly to identify a particular meaning of words or sentences and to obtain codes based on the similarities and differences in meaning. Then, the meaning of the significant sentences was explained by collecting and organising the formulation of the category. The next steps were to convert description into themes, which resulted in the validation theme. Categories and themes were extracted from the main idea of the statement and the sentence, which were stated by the participants during the interview process. Data collection was conducted simultaneously with the data analysis process until data saturation occurred.

\section{RESULTS}

Participants came from six families living in Jember Regency, each comprising the mother, father, aunt and siblings. There were seven post-pasung patients with a mental disorder, three women and four men. The length of pasung ranged from 7 days to 10 years. Five post-pasung patients with a mental disorder were caged, one patient had been chained, and the other was restrained by a

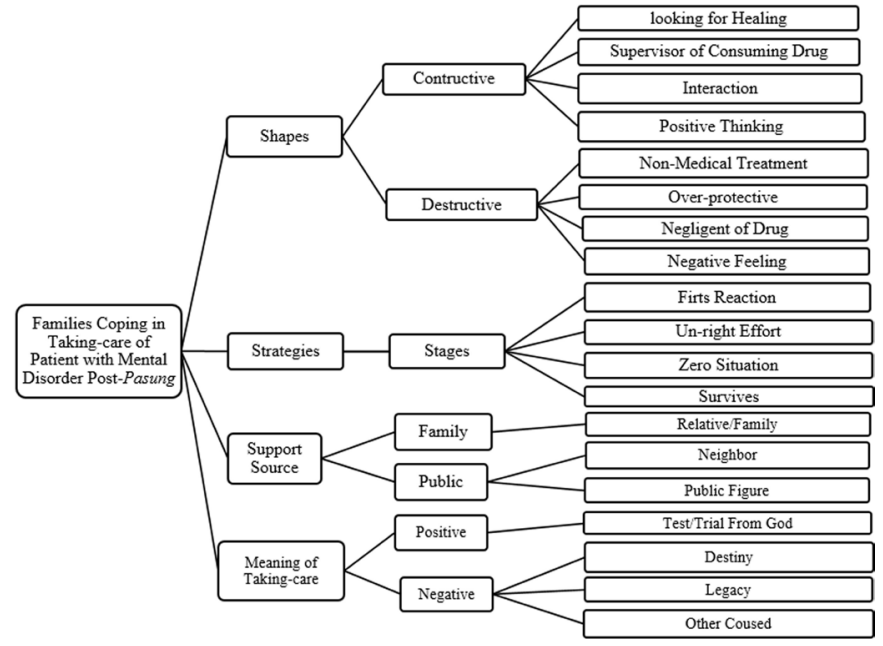

Figure 2 Appearance of families coping in taking care of patients with mental health post-pasung.

beam (table 1). Seven themes were found in this study (figure 2), and these are described below.

\section{Category 1: types of coping}

Theme 1: constructive coping

Based on interviews with six participants, the first subtheme was to look for healing and the first section was to bring patients to the nurse or doctor or do self-treatment, which was used by three participants.

"...we brought him to nurse and left him there..." (P2)

"...we were told to buy medicine. We bought injection medicine" (P3; P6)

Table 1 Characteristics of participants and post-pasung patients with mental disorders

\begin{tabular}{|c|c|c|c|c|c|c|c|c|}
\hline Participants & $\begin{array}{l}\text { Age } \\
\text { (Years) }\end{array}$ & Sex & Last education & Ethnicity & Occupation & $\begin{array}{l}\text { Relations } \\
\text { with patients } \\
\text { with mental } \\
\text { disorders }\end{array}$ & $\begin{array}{l}\text { Patients with } \\
\text { mental disorders } \\
\text { pasung duration }\end{array}$ & Pasung method \\
\hline $\mathrm{P} 2$ & 50 & Female & No qualification & Maduranese & Rujak Seller & Mother & 1 week & Chained \\
\hline P3 & 62 & Female & $\begin{array}{l}\text { Fourth grade } \\
\text { Elementary }\end{array}$ & Maduranese & Grocery owner & Mother & 1 year & $\begin{array}{l}\text { Chained to wood } \\
\text { beam }\end{array}$ \\
\hline \multirow{3}{*}{$\begin{array}{l}\text { P5 (three } \\
\text { interviewees) }\end{array}$} & 65 & \multirow[t]{3}{*}{ Female } & Elementary & Javanese & Farmer & Mother & \multirow[t]{3}{*}{10 years } & \multirow[t]{3}{*}{ Locked in cage } \\
\hline & 52 & & Senior High & Javanese & Housewife & Aunt 1 & & \\
\hline & 54 & & Senior High & Javanese & Housewife & Aunt 2 & & \\
\hline $\begin{array}{l}\text { P6 (three } \\
\text { interviewees) }\end{array}$ & 37 & Female & Senior High & Javanese & Farmer & Siblings & 2 months & Locked in room \\
\hline
\end{tabular}

Pasung: treatment by doing restrain and seclusion to patients with mental disorder

ODGJ, Replace with "Patients with mental disorders" 
The second section of looking for healing sub-theme was to take the patients to Lawang Psychiatric Hospital.

"First, we brought him/her to Jember Hospital, and then we brought him/her to Lawang Psychiatric Hospital" (P1; P2; P3; P4)

The second sub-theme was supervision of regular drug consumption.

"...She/he drinks drugs routinely. I make sure that the patients drink medicine routinely" (P5; P6)

All participants said that they made an effort to take drugs from the health centre/drugstore.

"Please buy the drugs like this one for your siblings/ child"

The third subtheme was interaction. Involving the patient in normal activity was the section of this subtheme.

"Sometimes, she eats alone. When she is cooking, the relapse occurs" (P1)

"... and then tidy up the kitchen......" (P2)

"He is rarely working" (P3)

"So I teach him/her to make a doormat" (P4)

"Now she is only sweeping the floor. She loves to sweep the floor" (P5)

"....later he will talk to welcome guests, friends, relatives ..." (P6)

The last sub-theme was positive thinking, which was indicated by positive feelings.

"I already feel calm" (P4)

"...the family feels pity for him. When you ask me whether I am tired, I am not feeling tired (at all)" (P6)

\section{Theme 2: destructive coping}

The destructive coping theme consisted of four subthemes. The first sub-theme was going to non-medical or alternative therapies, which was divided into two sections. The first section was going to meet a religious teacher.

"...I have already exorcised her there a few times" (P1)

"... We have already seen a lot of the Islamic religious teachers" (P6)

The second section in this sub-theme was visiting a shaman. All participants had asked a shaman for a help except for the fifth participant.

"We've already brought him/her to numerous shamans and it still doesn't work" (P1; P2; P3)

".... the way is by being brought to the shaman" (P4:P6)

The second sub-theme was an overprotective attitude, which had two sections. The fourth and the sixth participants were included in the first section because they were not allowed to go outside the home and two participants were accompanied at all times.

"He/she is not going anywhere. No one told him/her to go to work" (P4)

"We only monitor him when (he) goes somewhere....." (P6)

"...Because of that, I am afraid to leave her alone" (P1)

"Yes, I accompany him..." (P2)

The third sub-theme was supervision of drug consumption, which had two sections. The first section was mistakes in drug-taking.

"If he is not taking the medicine, I mix it (the drugs) with sugar" (P2)

"Actually he needs this drug only in the morning and afternoon, but he takes it only in the afternoon when he wants to sleep" (P3)

The next section was not taking medicines regularly.

"Sometimes she takes the drugs, but sometimes she does not take it" (P1)

"For a few days, he did not take the drugs, which means he rarely consumes the drugs" (P2)

"(So), the way he consumes the drugs is not routinely" (P3)

"...he took the drug late for 2 days" (P4)

The fourth sub-theme was negative feelings. This section was felt by almost all participants except for the fourth and sixth participants:

"If this is tiring, of course this makes me tired, but he/she is my child" (P1; P2)

"(Yes) we feel pity for his/her condition, why couldn't it just be healed a long time ago" (P3)

"Caretaking is tiring over a long period of time" (P5)

\section{Category 2: strategies}

Theme 3: strategic process stages

The first sub-theme was first reaction, which had one section, namely unawareness of the situation.

“...I also never expected it to happen” (P1; P3; P5)

"At first, no one knew about his condition, but after he came home, the condition was already worrying."

The second sub-theme on the coping strategy process was efforts in seeking medication. The section from this subtheme was going to a religious teacher or shaman as the first step.

"We have already taken him/her to numerous shamans everywhere..." (P2; P3; P4) 
"From the beginning, he already took the nonmedical treatment, for instance, going to the shaman, Islamic religious teacher, or alternative health service..." (P6)

The third sub-theme was the third stage of the coping strategy process that was being in the lowest point in their lives, which was running out of money for treatment. All participants of this study experienced the same thing, except for the fifth participant who was already in a state of deprivation/poverty.

“...I already have nothing" (P1)

"...we had sold over two cows for medication" (P2)

"...before he/she was taken to Lawang Psychiatric Hospital, I had already lost much money" (P3; P4)

"We had lost four hundred in a month for medication. After that, I had already sought a loan. There was no funds, so we were back home" (P6)

The fourth sub-theme was surviving the situation.

“...She just cannot be cured...." (P5)

The second section in this sub-theme was continuation of finding ways towards healing.

“... If we do not have anything left, we will sell our house. Of course, we will try till there are positive results" (P1)

"...if only someone can heal him/her, for sure we will pay them (whatever amount of money is needed)" (P3)

"...they told us to go everywhere, we still count them as an effort" (P6)

\section{Category 3: support sources}

\section{Theme 4: intrafamily support}

This theme had one sub-theme and one section. The subtheme was relatives, excluding the core family.

"Yes, we call it moral suport. Everyone is helping. Relatives and families are helping us for the medication" (P2; P6)

\section{Theme 5: public support}

This fifth theme had two sub-themes and six sections. The first sub-theme was neighbours, which had two sections. Two participants experienced the first section, which was material support.

"Thanks to God, we have neighbours who always give some food including rice and sometimes they give us some money" (P4)

“...Neighbours also give us food ..." (P5)

The first participant said they received help in the form of a calming relief when the post-pasung patient with mental disorder relapsed.
"They who live in the green house can help when the child relapses" (P1)

The next sub-theme was the government or social figure. This sub-theme had four sections, the first of which was community health insurance.

“...... government was giving free treatment through community health insurance" (P6)

The second section in this theme was a free-from-pasung programme and treatment provided by the government through Social Services and District Level Health Office of Jember.

"...We get cumulative aid from numerous government agencies." (P2)

"... Medical officer of the health office came here, seeking patients who were locked up." (P3)

"...The government brought him to Lawang Psychiatric Hospital.” (P4)

The next section was the assistance of health officers (nurse/midwife/religious teacher). Participant number 4 was included in this category.

"A long time ago, we were helped by Ms Dian (the midwife)" (P4)

The last section in the fifth theme was a local government official. Only two participants received support from this section.

"And then Mr Lu brought people from the government agency here. $\mathrm{Mr} \mathrm{Lu}$ is district government employee" (P3)

"...Finally, the district agency surveyed us. Then, they felt sorry" (P5)

Category 4: meanings of taking care of post-pasung patients with mental disorders

Theme 6: positive meanings

This positive meaning had a sub-theme, including the test/trials from God, and had three sections: sincerity, patience, and helplessness.

“...we are acquiescent and consider it as a test/trial from God” (P6)

The patience section was perceived by the second and fourth participants.

"Father has patience" (P2)

"I am patient, but I don't understand how to treat him, and we just can't be rude to him/her" (P4)

The next section, helplessness, was felt by the third participant.

"Yes, it is a test/trial from God and we can't do anything (about that)" (P3)

"Yes, this is a test/trial from God. Accepting everything from God... I have nothing to say" (P4) 
"I already surrender" (P6)

\section{Theme 7: negative meanings}

This seventh theme was divided into three sub-themes and four sections. The first sub-theme was mental disorder caused by sorcery/trance/being possessed by a demon.

"(yes) but I do not know. Several people said that there is someone that sent black-magic (to my child)" (P1)

The next section was event-based. Participant number 2 felt that this incident stemmed from an event.

"Yes. He almost got married but his engagement was canceled. $e$ tried to do suicide by falling-down from rooftop. Then, he started drinking and getting bullied" (P2)

The 19th sub-theme was fate, which had an incurable section, and the 21st sub-theme was legacy, which had the ancestry section. The fifth participant was interpreted according to this sub-theme.

"It's impossible to be cured. Her mother had been diagnosed with mental disorder before" (P5)

\section{DISCUSSION}

\section{Main findings}

There were three coping models performed by parents. One of them was productive coping, including problem solving, hard work, involvement, positive thinking, resting, and physical entertainment. ${ }^{13}$ After being analysed, all participants also used this coping model. Productive coping was done by the family in taking care of the post-pasung patient with mental disorder by bringing them to a nurse or doctor, making appointments at the outpatient clinic, giving medication, bringing them to Lawang Psychiatric Hospital, having them routinely take their medicine, taking their drug prescriptions to the primary care clinics or buying medicine, involving them in normal activity, and having a positive feeling.

The destructive coping in this study showed four coping features. Families with a destructive coping condition conducted treatment by visiting non-medical or alternative therapies, being over protective of the patient, neglecting medication control, and having negative feelings in regards to taking care of the post-pasung patient with a mental disorder. Destructive coping was a coping condition that negatively impacted the post-pasung patient with a mental disorder.

Negative feelings also became a destructive coping condition. Feelings of burden embodied the expression statement of being annoyed, tired, and pitiful. Families with members who have a mental disorder experience objective and subjective burdens and also lifelong stress. ${ }^{14}{ }^{15}$ In 2008, WHO classified the burden experienced by families into two subjects: subjective burden associated with the psychological reaction of family members; and objective burden which was a limitation of social relations and work activities. The burden could be felt as a psychological burden, physical burden, and financial burden related to the treatment cost for the patient with a mental disorder. ${ }^{16}$

This study illustrated that the family coping condition was not limited to one coping condition-in other words, the coping condition fluctuated. The family's coping condition was influenced by various factors, including the types of problems faced by the family. Each participant tended to be dominant against one of the coping conditions, if they faced the same problem or situation equally. However, the condition might change or still remain when participants encountered new problems or new situations. Coping was complex and took time. One coping strategy used by a person tended to be stable and consistent during the times of high pressure. Coping might change from one time to another when an individual faced certain stressors (stress conditions) because coping was a process. ${ }^{17}$

Strategic process stages were divided into four stages. The first was the initial situation stage, which had an unawareness section. In the early phase of the situation, families tended to not realise the initial situation of family members experiencing a mental disorder. Almost all participants experienced the same initial situation. The family never suspected or thought that members of their family had a mental disorder. Instead, they thought of other circumstances (mainly mystical events). They did not understand why or how their family member had a mental disorder and what caused the disorder. The second phase was looking for healing from non-professionals (ie, a shaman). Because the family assessed that members of their family had experienced mystical things, they then entered the second stage of looking for healing from nonmedical treatment; therefore, the medication process was not relevant. Two participants also did that, but not in the early stages. However, they did so along with medical treatment.

The third stage was being in the lowest point in their lives, which meant having insufficient funds for treatment. The situation occurred due to the previous stage: visiting the shaman repeatedly in different places, but achieving no results, so that they then ran out of money. The last phase was surviving the situation. At this stage, there were two sections. The first section was to go through the situation and continue to look for ways of healing. This stage was the final process of delivering families to the coping strategies and mechanisms chosen for treating the postpasung patient with a mental disorder and determining the family's coping response. The section underwent a situation reflected in maladaptive responses due to the poor family efforts to improve the recovery process of the patient with a mental disorder. Meanwhile, continuing to find a way of healing was reflected in the adaptive coping response. This section illustrated that families were actively pursuing efforts to find ways to improve the mental health and recovery of the patient with a mental disorder. 
The support source of the family was something that could have a sufficient impact on the stressful event and the family stress level.$^{18} 19$ In this study, two coping resources were obtained by participants from intra-family and public support. Stuart also stated that the coping source could be found internally and externally. Support sources in the form of financial assets, problem solving skills, social support, and cultural beliefs could help with integration of stressful experiences into real life and, thus, individuals learn to adopt a successful coping strategy. ${ }^{11}$ The research showed that intra-family coping support was categorised as the external family circle of the patients with a mental disorder. Support provided were material support (money) and non-material support (services, treatment, etc).

Internal family coping or intra-family coping included relying on family groups, having a sense of humour, maintaining family ties, controlling the meaning and significance of the problem, solving problems together, maintaining flexibility, and normalisation. ${ }^{20}$ The term source of family support referred to the family's internal attributes in protecting the family from the impact of stressors and in facilitating the family adaptation process throughout the period of stress and/or crisis. Family cohesion (unity bond) and adaptability (ability to change) were two things in the family that tended to make adjustments to stress more successful (with the results of more successful coping). ${ }^{18}$

Public support was a family coping support system from the external family circle. Public support on this study was the supporter, the surrounding community, and the environment. Sources of social support included: spontaneous and informal networks, organised support of nonhealth workers, and organised support of health workers. In general, public support was used as a protective effect against stress and it promoted recovery from stress or crisis. ${ }^{20}$ This study produced two forms of family coping support sources, including public support-that is, neighbours and government/social figures.

The appearance of the source of family coping support in taking care of the post-pasung patient with a mental disorder showed that support for each participant did not always come from one direction, but from various directions. This support was influenced by various factors, for example, culture, interaction with the surrounding environment, community acceptance, and social sensitivity. Social support affected the process of acceptance for patients and their families. ${ }^{21}$

The intended meaning was family assessment or family perception of what the family members (patient with mental disorder and their families) were experiencing. Being influenced by a source of coping, the person could find meaning in a stressful experience and consider alternative strategies to cope with stressful events. ${ }^{11}$ This study gave two types of meaning to take care of the post-pasung patient with a mental disorder, which were positive meanings and negative meanings. The results illustrated only a small fraction who could obtain positive meanings from their experiences. This could be seen from the statements of both participants, which expressed more than one perspective.

The negative meaning perceived by the family affected the process of survival and recovery for the post-pasung patient with a mental disorder. Basically, the negative meaning was related to family dissatisfaction in overcoming the problem of taking care of the patient. The negative meaning could develop and increase the stress level on the family. Valuation and signification of negative life events could increase the stress level by all family members. ${ }^{22}$ Theoretically, the impact of the stress events source was influenced by the definition or meaning that was felt by the family from the event. The subjective definition of the family might vary. They could see the situation as a challenge and a chance to grow, or as a negative view that everything was hopeless, too difficult, or unmanageable. The empirical findings showed that the individual's cognitive judgement of life events strongly influenced the response, and it was perhaps the most important component in determining an individual or family response to a stressor event. ${ }^{18}$

The stress adaptation model by Stuart ${ }^{11}$ did not explain the stages of the strategy process in determining the choice of coping mechanism ${ }^{11}$. Therefore, the researchers tried to describe the stages of the strategy process based on interviews with the participants and analysis of the relevant literature. The stress adaptation model touching on the source of the coping support was an option or strategy to help determine what can be at stake. The existence of a support source might take the available coping options into consideration, the possibility of the given option will be successful, and the person can effectively implement the strategy. Stuart's sources of support included economic assets, abilities and skills, social support, and motivation, and incorporated all social levels (relationships between individuals, families, groups and communities). This research categorised coping support sources into two groups, which were intra-family and public supports. Both categories were a form of support source transformation proposed in the stress adaptation model.

Coping strategies focus on perception of the situation. A positive meaning led to a spiritual judgement that what happened in the family was a test or trial from God. This spiritual judgement then produced several attitudes, for example, acquiescent, patient, or surrendered attitudes. Positive meanings would have a positive impact on the recovery process of the post-pasung patient with a mental disorder. Meanwhile, more negative meanings were towards negative judgements, namely, events caused by some particular things (destiny or lineage). Negative meanings tended to lead families to maladaptive responses.

\section{Limitations}

There are several limitations of the present study. First, this study employed a semi-structured interview with the method of in-depth interview as a method for collecting data. The limited experience of researchers in extracting 
data through interviews would affect the level of depth and breadth of data obtained. Second, participants in this study were characteristically old and some participants were Madurese. Thus, the terms appeared to be culture-based terms.

\section{Implications}

The appearance of family coping was generally constructive or destructive coping, where the situation fluctuated depending on the problem and the situation. The family coping strategy process was carried out in four stages. The first stage was the early phase of the family in which they were unaware of the situation that was happening to members of their family. In the second stage, the family would look to non-professional parties such as a shaman for help. In the third stage, the family was in a state of insufficient funding. Meanwhile, in the fourth stage, the family survived the situation. The source of family coping support was obtained from intra-family and public support. The meaning of this description was that the family felt the experience in positive and negative ways. Our results suggested that the primary healthcare centre is expected to be able to provide several mental health service programmes in the community, including counselling for those whose family members have a mental disorder or are post-pasung patients with a mental disorder. Finally, an occupational therapy programme, monitoring and home visits, and counselling for families could strengthen family coping strategies.

Contributors Conception and design: FCY and HEN. Analysis and interpretation of the data: FCY, AY and NHH. Drafting of the article: NHH. Critical revision of the article for important intellectual content: FCY. Final approval of the article: AY and HEN. Provision of study materials or patients: FCY. Obtaining of funding: AY and HEN. Administrative, technical, or logistic support: AY and NHH. Collection and assembly of data: HEN.

Funding The authors have not declared a specific grant for this research from any funding agency in the public, commercial or not-for-profit sectors.

Competing interests None declared.

Patient consent for publication Parental/guardian consent obtained.

Ethics approval This study received a certificate of ethical clearance from ethical commission No. 443-KEPK, on 26 July 2017.

Provenance and peer review Not commissioned; externally peer reviewed.

Data availability statement Data are available upon reasonable request.

Open access This is an open access article distributed in accordance with the Creative Commons Attribution Non Commercial (CC BY-NC 4.0) license, which permits others to distribute, remix, adapt, build upon this work non-commercially, and license their derivative works on different terms, provided the original work is properly cited, appropriate credit is given, any changes made indicated, and the use is non-commercial. See: http://creativecommons.org/licenses/by-nc/4.0/.

\section{REFERENCES}

1 Minas H, Diatri H. Pasung: physical restraint and confinement of the mentally ill in the community. Int J Ment Health Syst 2008;2:8.

2 Halida N, Dewi El, Rasni H. Pengalaman Keluarga dalam Pemenuhan Kebutuhan Perawatan pada Orang dengan Gangguan Jiwa (ODGJ) dengan Pasung di Kecamatan Ambulu Kabupaten Jember. E Jurnal Pustaka Kesehatan 2016;4.

3 Mukhalladah DA. Pengalaman Keluarga Merawat Klien Gangguan Jiwa Pasca Pasung. Skripsi: Universitas Airlangga Surabaya, 2016.

4 Wijayanti AP, Masykur AM. Lepas Untuk Kembali Dikungkung: Studi Kasus Pemasungan Kembali Eks Pasien Gangguan Jiwa. Jurnal Empati 2016:5:786-98.

5 Indriani R. Mensos: Kasus Pemasungan Terbanyak Jatim, 2016. Available: http://www.suara.com/news/2016/12/04/013100/mensoskasus-pemasungan-terbanyak-di-jatim [Accessed 15 Dec 2016].

6 Yusuf A, Putra ST, Probowati Y. Peningkatan coping Keluarga dalam Merawatn Pasien Gangguan Jiwa Melalui Terapi spiritual direction, obedience, DAN acceptance (DOA). Jurnal Ners 2012;7:196-202.

7 Wardhaningsih S, Rochmawati E, Sutarjo P. Gambaran Strategi Koping Keluarga dalam Merawat Pasien Skizofrenia di Wilayah Kecamatan Kasihan Bantul. Mutiara Medika 2010;10:55-61.

8 Wanti Y, Widianti E, Fitria N. Gambaran Strategi Koping Keluarga dalam Merawat Anggota Keluarga Yang Menderita Ganggua Jiwa Berat. Jurnal Keperawatan Padjajaran 2016;4:89-97.

9 Folkman S, Lazarus RS. Way of coping questionnaire. Journal O Personality and Social Psychology 1988;48.

10 Patterson McC. Coping health inventory for parents (CHIP), 1983.

11 Stuart GW. Principles \& Practice of Psychiatric Nursing. 9th edn. Philadelphia: Elssevier Mosby, 2013.

12 Streubert H, Carpenter D. Qualitative research in nursing: advancing the humanistic imperative. Philadelphia: Lippincott Williams \& Wilkins, 2003.

13 Claker AL, Critchley C. Impact of choice of coping strategies and family functioning on psychosocial function of young people with epilepsy. Journal of Epilepsy and Behavior 2016:50-6.

14 Yusuf $A$, Yunitasari $E$. The increase of family's health belief in mental disorder with spiritual approach. J Appl Environ Biol 2015;5:345-50.

15 Yusuf A, Fitriasari PK, Nihayati HE, et al. Nursing competencies in taking care of patient with mental health disorders. Journal Ners 2016;11.

16 Sari H. Pengaruh family Psychoeducation terhadap beban DAN kemampuan keluarga dalam merawat klien pasung di Kabupaten Bireun. Depok: Universitas Indonesia, 2009.

17 Lazarus RS. Coping theory and research: past, present, and future. Psychosom Med 1993;55:234-47.

18 Price SJ, Price CA, McKenry PC. Families coping with change: a conceptual overview, 2010.

19 Yusuf A, Tristiana RD, Purwo IG. Fenomena Pasung dan Dukungan Keluarga terhadap Pasien Gangguan Jiwa Pasca Pasung. JKP 2017;5.

20 Ngadiran A. Studi Fenomenologi Pengalaman Keluarga Tentang Beban DAN Sumber Dukungan Keluarga dalam Merawat Klien Halusinasi. Depok: Universitas Indonesia, 2010.

21 Zefry M, Purnama W. Dukungan Sosial dengan Penerimaan Diri pada Penderita Gagal Ginjal, 2016.

22 Hidayah R. Studi Fenomenologi: Strategi Koping Orang Tua dalam Merawat Anak dengan autism Sprecrum disorder (ASD). Surabaya: Universitas Airlangga, 2015.

Fildzah Cindra Yunita graduated from Faculty of Nursing Universitas Airlangga Surabaya Indonesia in October 2017. She used to work as a manager editor of Biomolecular and Health Science Journal until May 2018. Now, she is working as a research assistant. She has a publication in Indonesian scholar's journal on Indonesia Ageless Island: Optimizing the Gili-Iyang as Conservation Area with Highly O2 for Tourist Resort. Her paper also was accepted as a poster presentation in the 48th Asia-Pacific Academic Consortium for Public Health Conference by title Health Screening Corner (HSC): a Solution to prevent Travel-related Tropical Disease in Indonesia. Her research interests include mental health, psychiatry and community health. 